\title{
Spatial distribution of Anopheles gambiae sensu lato larvae in the urban environment of Yaoundé, Cameroon
}

\author{
Landre Djamouko-Djonkam ${ }^{1,2}$, Souleman Mounchili-Ndam ${ }^{1,3}$, Nelly Kala-Chouakeu ${ }^{1,2}$, \\ Stella Mariette Nana-Ndjangwo ${ }^{1,3}$, Edmond Kopya ${ }^{1,3}$, Nadége Sonhafouo-Chiana ${ }^{1,4}$, Abdou Talipouo ${ }^{1,3}$, \\ Carmene Sandra Ngadjeu ${ }^{1,3}$, Patricia Doumbe-Belisse ${ }^{1,3}$, Roland Bamou ${ }^{1,2}$, Jean Claude Toto ${ }^{1}$, \\ Timoléon Tchuinkam ${ }^{2}$, Charles Sinclair Wondji ${ }^{5}$ and Christophe Antonio-Nkondjio ${ }^{1,5^{*}}$
}

\begin{abstract}
Background: The rapid and unplanned urbanization of African cities is considered to increase the risk of urban malaria transmission. The present study objective was to assess factors influencing the spatio-temporal distribution of Anopheles gambiae s.l. larvae in the city of Yaoundé, Cameroon.

Methods: All water bodies were checked once every 2 months for the presence of mosquito larvae from March 2017 to May 2018 in 32 districts of Yaoundé. Physico-chemical characteristics including the size, depth, turbidity, pH, temperature, conductivity, sulfates, organophosphates, hydrogen peroxide $\left(\mathrm{H}_{2} \mathrm{O}_{2}\right)$, conductivity, iron and calcium were recorded and analyzed according to anopheline larvae presence or absence. High resolution satellite images from landsat sentinel Enhanced Thematic Mapper were used for spatial mapping of both field and environmental variables. Bivariate and multivariate logistic regression models were used to identify variables closely associated with anopheline larvae distribution.
\end{abstract}

Results: A total of 18696 aquatic habitats were checked and only 2942 sites (15.7\%) contained anopheline larvae. A high number of sites with anopheline larvae $(\geq 69 \%)$ presented late instar larvae ( $L 3, L 4$ and pupae). Anopheline mosquito larvae were sampled from a variety of breeding sites including puddles (51.6\%), tire prints (12.9\%), wells (11.7\%) and drains (11.3\%). Bivariate logistic regression analyses associated anopheline larvae presence with the absence of predators, absence of algae, absence of vegetation and depth of less than $1 \mathrm{~m}$. Conductivity, turbidity, organophosphates, $\mathrm{H}_{2} \mathrm{O}_{2}$ and temperature were significantly high in breeding sites with anopheline larvae than in breeding sites without these larvae $(P<0.1)$. Anopheline species collected included An. coluzzii (91.1\%) and An. gambiae s.s. (8.9\%). GIS mapping indicated a heterogeneous distribution of anopheline breeding habitats in the city of Yaoundé. Land cover analysis indicated high variability of the city of Yaoundé's landscape.

Conclusions: The data confirms adaptation of An. gambiae s.l. to the urban domain in the city of Yaoundé and calls for urgent actions to improve malaria vector control.

Keywords: Larval habitat, Anopheles dynamics, Urban environment, Malaria, GIS, Yaoundé, Cameroon

\footnotetext{
* Correspondence: antonio_nk@yahoo.fr

'Malaria Research Laboratory, Organization for the fight against Endemic

diseases in Central Africa (OCEAC), P.O. Box 288, Yaoundé, Cameroon

${ }^{5}$ Vector Biology Liverpool School of Tropical medicine Pembroke Place,

Liverpool L3 5QA, UK

Full list of author information is available at the end of the article
}

(c) The Author(s). 2019 Open Access This article is distributed under the terms of the Creative Commons Attribution 4.0 International License (http://creativecommons.org/licenses/by/4.0/), which permits unrestricted use, distribution, and reproduction in any medium, provided you give appropriate credit to the original author(s) and the source, provide a link to the Creative Commons license, and indicate if changes were made. The Creative Commons Public Domain Dedication waiver (http://creativecommons.org/publicdomain/zero/1.0/) applies to the data made available in this article, unless otherwise stated. 


\section{Multilingual abstracts}

Please see Additional file 1 for translations of the abstract into the five official working languages of the United Nations

\section{Background}

The rapid unplanned urbanization of sub-Saharan Africa cities, is significantly affecting the epidemiology of vector borne diseases [1-8]. During the last decade, several outbreaks of chikungunya and dengue have been reported in major cities across sub-Saharan Africa [9-12]. For malaria, although successful scale up of control tools such as long lasting insecticidal nets (LLINs) and indoor residual spraying permitted to reduce the global burden of the disease across the continent [13], the disease is still highly prevalent in most urban settings [2, 14-17]. The fast growing urban population is considered to exert a high pressure on land resources resulting in the colonization of marshland and swamps and expansion of deforestation. The said conditions occurring at a large scale, create suitable breeding opportunities for mosquitoes increasing by then, malaria transmission risk in urban settings. Understanding anopheline larvae dynamic in this changing environment becomes imperative for the implementation of successful control measures.

In Cameroon, malaria is highly endemic and the whole country is exposed to the risk of transmission [18]. Although increased malaria transmission has been reported in urban settings [14], there is still not enough data on the spatio-temporal distribution of anopheline population breeding habitats. The characterization of anopheline breeding sites in the cities of Douala and Yaoundé indicated that anopheline larvae could colonize polluted breeding sites and that this adaptation could affect the susceptibility level of adult mosquito populations to insecticides [19]. The study by Kamdem et al. [20] along a transect between rural and urban settings, suggested that ecological correlates and some environmental indicators, could be good predictors for discriminating the distribution of $A n$. gambiae sensu stricto and $A n$. coluzzii in the city of Yaoundé [20]. However, the study did not provid detailed information on the spatio-temporal distribution of anopheline breeding habitats in the city. Indeed, information on the spatial distribution of mosquito breeding habitats is required to enable tracking and targeting hotspot areas where there is persistent presence of vector populations. The development of geographic information systems (GIS) mapping technology now provides an opportunity to have affordable and scalable approaches that deliver high resolution maps of mosquito distribution or transmission risk which could enable better surveillance system [21].
In Cameroon, insecticide-treated nets are the main measures used for controlling mosquito populations but this measure is affected by the rapid emergence of insecticide resistance particularly in urban settings $[22,23]$. In this context, a deep understanding of the influence of ecological factors and spatio-temporal distribution of mosquitoes could enable the implementation of new interventions such as larval control to improve the performance of interventions implemented in the field. Compared to East Africa, there has been little effort in using larval source management for controlling vector-borne diseases in Central Africa [24-27]. Larval control has proved to be efficient in situation where habitats are few, fix and manageable [28-32]. In most sub-Saharan Africa cities, malaria transmission is focal and depends on the existence of hotspot areas [2, 27, 33-35]. Identifying these hotspot areas and mapping the distribution of anopheline species across the year could be key for the implementation of a successful and sustainable program for malaria control and elimination in urban settings.

The aim of the present study was to assess the spatiotemporal distribution of aquatic stages of anopheline mosquitoes in Yaoundé and the influence of physicochemical parameters and the landscape on anopheline species distribution.

\section{Methods \\ Study area}

The study was conducted in Yaoundé $\left(3^{\circ} 43^{\prime} 00^{\prime \prime}\right.$ to $3^{\circ} 58^{\prime} 00^{\prime \prime} \mathrm{N}$ and $11^{\circ} 24^{\prime} 30^{\prime \prime}$ to $\left.11^{\circ} 34^{\prime} 30^{\prime \prime} \mathrm{E}\right)$, the capital city of Cameroon. Yaoundé is a town covering a surface area of $304 \mathrm{~km}^{2}$ of about 3 million inhabitants situated between 700 and $750 \mathrm{~m}$ above sea level. The city is drained by several permanent streams and is situated within the Congo-Guinean phytogeographic zone [36]. The climate is of equatorial type with four seasons (two rainy seasons [September-November and March-June], two dry seasons [December-February and July-August]) [37]. The average rainfall in Yaoundé is estimated at $1688 \mathrm{~mm} /$ year, thaverage annual temperature is of $26.31{ }^{\circ} \mathrm{C}$ varying between 16 to $33{ }^{\circ} \mathrm{C}$ depending on the season. The average humidity is $80 \%$ and varies during the day between 35 to $98 \%$ [38]. The city is exposed to frequent humid winds blowing south-west to west or north to west [39].

Spatial and temporal mapping of water bodies using the geographic information system (GIS)

High resolution satellite images from landsat sentinel Enhanced Thematic Mapper (ETM) at the resolution of $15 \mathrm{~m}$ were acquired for the city of Yaoundé. Images used were from two distinct periods May 2017 


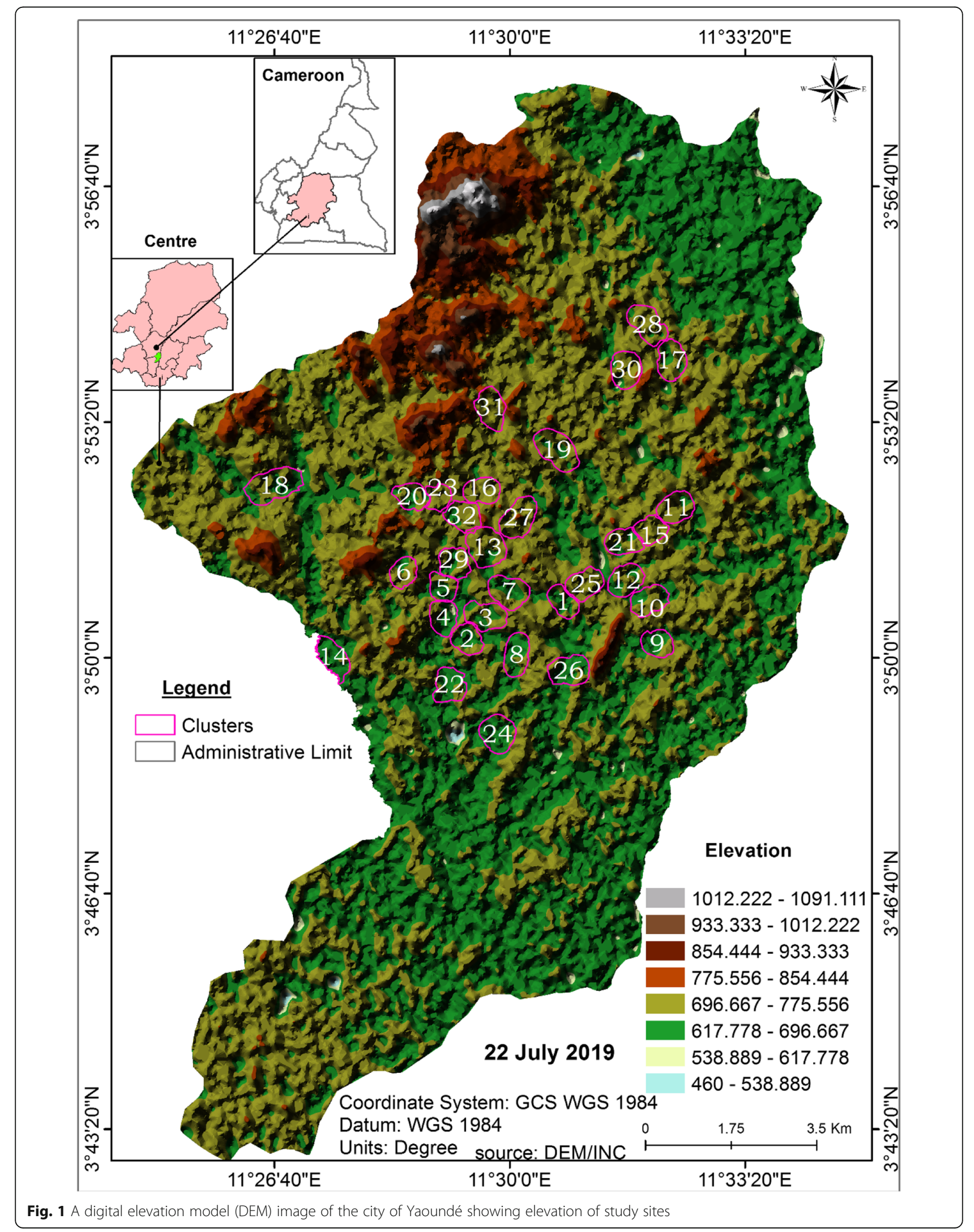


and June 2018. The satellite image includes four spectral bands green, red, blue and near-infrared. The image was projected to Universal Transverse Mercator (UTM) zone 32 on the World Geodetic System (WGS) 84 Datum. The image was analyzed using the software Erdas Imagine 2014 (Géomatica-SIG and télédetection-Intergraph, US). A supervised classification was applied. A training dataset was selected on the satellite image manually by digitizing multiple training polygons for each class. One hundred training sites were obtained for each of the land cover as done elsewhere [40]. Data recorded for spatial mapping included both field and environmental variables. On the field the geographical coordinates of all breeding habitats were registered using a Garmin-branded GPS (Garming eTrex 10 Handheld). Data extraction was done using Mapsource software. Once collected, field data were crosschecked and link to GPS coordinates for each district with a unique code for each data. All the geo-databases were then registered in ArcGIS 10.2.2 software (ESRI, Redland, CA, USA). Arccatalog was used to construct the Geo-database that enabled visualization of the spatial distribution of breeding sites. Environmental variables including humidity, vegetation and soil indicators were calculated from the landsat sentinel 2 images. The Global Moran statistics index in ArcGIS was used to test for spatial autocorrelation [41]. The Normalised Difference Vegetation Index (NDVI) was calculated using the near infrared (NIR) and red spectral bands as (NIR-Blue)/(NIR + Blue). The Normalized Difference Water Index (NDWI) was calculated as (NIR-Green)/ (NIR + Green) [40]. Building Index (BI) calculations were done as follows $\mathrm{BI}=\mathrm{sqr}\left(\mathrm{NIR}^{2}+\operatorname{Red}^{2}\right)$. Calculations were done using Erdas Imagine 2014.

\section{Breeding sites sampling}

Mosquito breeding sites prospections were conducted in 32 districts out of about 100 in Yaoundé from March
2017 to May 2018 once every 2 months. The districts were characterized by an alternation of highland and lowland areas and extended from the city centre to the periphery (Fig. 1). Most of the lowland areas are irrigated by the river system in the city of Yaounde including Mfoundi, Biyeme and Mefou rivers, whose edges provide excellent breeding opportunities for mosquitoes during the dry season. The districts are highly populated with constructions in both highland and lowland areas. Marshlands along Mefou River are exploited for house construction and for the practice of market gardening during the dry season. These areas are the main sources of breeding habitats for mosquitoes. All water bodies encountered were geo-located using a Garmin eTrex $^{\circ}$ GPS and enter to a GIS database for analysis.

\section{Physico-chemical characterization of breeding sites larval collection and mosquito species identification}

Parameters recorded in each breeding site included breeding habitats type, size, depth, exposure to sunlight, presence of vegetation, the distance between each water body and the nearest human dwellings and the presence/absence of predators, the status organically polluted or not, the proportion of water surface covered by vegetation or algae, breeding sites type (stagnant water pools, gutters, well, tire print, footprint, pit latrine ....). In addition to these, the following parameters were also recorded Total Dissolved Solids (TDS) $\mathrm{pH}$, temperature, conductivity using a Jenway multiparametric probe. The concentrations of sulfates, organophosphates, hydrogen peroxide $\left(\mathrm{H}_{2} \mathrm{O}_{2}\right)$, turbidity, iron and calcium were analyzed using a Wagtech spectrophotometer [42].

All water bodies were checked for the presence of mosquito larvae. The immature stages of mosquitoes were collected using the standard dipping technique [43]. Three to five dips using a deeper of $350 \mathrm{ml}$ were performed for small breeding sites of less than $1 \mathrm{~m}^{2}$; and 5 to 10 dips were undertaken in breeding

Table 1 Characteristics of the different types of breeding habitats recorded in the city of Yaoundé

\begin{tabular}{|c|c|c|c|c|c|c|}
\hline Types of sites & $\begin{array}{l}\text { Number of sites } \\
(\%)\end{array}$ & $\begin{array}{l}\% \text { with anopheline } \\
\text { larvae }\end{array}$ & $\begin{array}{l}\text { \% with size < } 1 \\
\mathrm{~m}\end{array}$ & $\begin{array}{l}\%>25 \text { vegetation } \\
\text { coverage }\end{array}$ & $\begin{array}{l}\text { \% with } \\
\text { algae }\end{array}$ & $\begin{array}{l}\% \text { with culicine } \\
\text { larvae }\end{array}$ \\
\hline Puddles & 273 (51.6) & 50.5 & 44.3 & 17.2 & 17.9 & 22 \\
\hline Tire prints & 68 (12.9) & 67.6 & 58.8 & 2.9 & 7.3 & 22.1 \\
\hline Foot prints & $11(2.1)$ & 91 & 81 & 10 & 0 & 41 \\
\hline Wells & $62(11.7)$ & 17.7 & 51.6 & 11.3 & 30.6 & 11.3 \\
\hline Drains & $60(11.3)$ & 25 & 41.7 & 36.7 & 45 & 21.7 \\
\hline Furrows & $44(8.3)$ & 29.5 & 15.9 & 36.4 & 18.2 & 29.5 \\
\hline $\begin{array}{l}\text { Artificial } \\
\text { containers }^{a}\end{array}$ & $4(0.8)$ & 25 & 100 & 0 & 25 & 0 \\
\hline Others $^{b}$ & 7 (1.3) & 14.3 & 0 & 28.6 & 14.3 & 42.9 \\
\hline
\end{tabular}

${ }^{\mathrm{a}}$ Tyres and buckets; ${ }^{\mathrm{b}}$ Ponds, pits and Rivers edges 
Table 2 Characterization of anopheline larvae breeding sites

\begin{tabular}{|c|c|c|c|c|c|}
\hline Characteristics & Variables & Number of BS sampled & $\begin{array}{l}\text { Number of BS with } \\
\text { anopheline larvae (\%) }\end{array}$ & Odd ratio $(95 \%$ Cl) & $P$-value \\
\hline \multirow[t]{2}{*}{ Proximity to living habitats (meter) } & $\leq 10$ & 283 & $108(38.2)$ & 1 & 0.002 \\
\hline & $>10$ & 247 & $127(51.4)$ & $1.7(1.2-2.4)$ & \\
\hline \multirow[t]{2}{*}{ Size $\left(m^{2}\right)$} & $\leq 1$ & 228 & $138(60.5)$ & 1 & $<0.0001$ \\
\hline & $>1$ & 302 & $97(32.1)$ & $0.3(0.2-0.4)$ & \\
\hline \multirow[t]{2}{*}{ Depth (meters) } & $<1$ & 465 & $223(48.0)$ & 1 & $<0.0001$ \\
\hline & $\geq 1$ & 65 & $12(18.5)$ & $0.25(0.1-0.5)$ & \\
\hline \multirow[t]{3}{*}{ Permanency } & Temporal & 397 & $207(52.1)$ & 1 & $<0.0001$ \\
\hline & Semi-permanent & 64 & $16(25.0)$ & $0.3(0.2-0.5)$ & \\
\hline & Permanent & 69 & $12(17.4)$ & $0.2(0.1-0.4)$ & $<0.0001$ \\
\hline \multirow[t]{3}{*}{ Vegetation cover (\%) } & $0-25$ & 439 & $213(48.5)$ & 1 & $<0.0001$ \\
\hline & $25-75$ & 65 & $13(20.0)$ & $0.3(0.1-0.5)$ & \\
\hline & $75-100$ & 26 & $6(23.1)$ & $0.3(0.1-0.8)$ & 0.016 \\
\hline \multirow[t]{2}{*}{ Algae } & Present & 110 & $40(36.4)$ & 1 & 0.06 \\
\hline & Absent & 420 & $195(46.4)$ & $1.5(1.0-2.3)$ & \\
\hline \multirow[t]{2}{*}{ Culicine larvae } & Present & 115 & $38(33.0)$ & 1 & 0.3 \\
\hline & Absent & 414 & $158(38.2)$ & $1.3(0.8-1.9)$ & \\
\hline \multirow[t]{2}{*}{ Predators } & Present & 99 & $22(22.2)$ & 1 & $<0.0001$ \\
\hline & Absent & 431 & $213(49.4)$ & $3.4(0.2-5.7)$ & \\
\hline
\end{tabular}

BS Breeding site

sites of more than $1 \mathrm{~m}^{2}$. For some habitats such as tire print or foot print which could be too shallow at some periods, larval collection was conducted using a pipette. The average larval density $(\mathrm{N})$ was estimated as the ratio of the number larvae collected per dip (using a dipper with a volume of $350 \mathrm{ml}$ ). Once collected larvae were classified according to their stages: early instars larvae (L1 and L2) and late instars (L3, L4 and pupa). Anopheline larvae were separated from the culicines using morphologically identification keys $[44,45]$. Each anopheline larvae specimen was stored individually at $-20^{\circ} \mathrm{C}$.

Mosquitoes larvae belonging to the An. gambiae complex were further processed by PCR [46], to distinguish $A n$. coluzzii from An. gambiae s.s. the two members of the complex found in Yaoundé. DNA extracted from larvae according to Livak protocol [47], were used for these analyses.

Table 3 Comparison of physico-chemical characteristics between sites with and without anopheline larvae

\begin{tabular}{|c|c|c|c|c|c|c|}
\hline \multirow[t]{2}{*}{ Parameter } & \multicolumn{2}{|c|}{ With anopheline larvae } & \multicolumn{2}{|c|}{ Without anopheline larvae } & \multirow[t]{2}{*}{$t$-test } & \multirow[t]{2}{*}{$P$-value } \\
\hline & $N$ & Means \pm SE & N & Means \pm SE & & \\
\hline $\mathrm{pH}$ & 227 & $8.0 \pm 0.1$ & 286 & $7.8 \pm 0.1$ & 1.6 & 0.2 \\
\hline TDS (mg/L) & 240 & $96.2 \pm 16.8$ & 300 & $93.9 \pm 9.6$ & 0.6 & 0.4 \\
\hline Conductivity ( $\mu \mathrm{s} / \mathrm{cm})$ & 240 & $449.0 \pm 29.8$ & 300 & $382.9 \pm 14.6$ & 3.9 & 0.05 \\
\hline Turbidity (FTU) & 240 & $380.9 \pm 103.8$ & 300 & $146.0 \pm 18.7$ & 10.5 & 0.001 \\
\hline Calcium (mg/L) & 240 & $53.7 \pm 21.7$ & 300 & $129.7 \pm 85.6$ & 2 & 0.16 \\
\hline Iron LR & 108 & $0.7 \pm 0.1$ & 118 & $0.7 \pm 0.1$ & 0 & 0.98 \\
\hline Organophosphates (mg/L) & 138 & $13.3 \pm 4.2$ & 158 & $9.0 \pm 0.8$ & 3.5 & 0.06 \\
\hline Aluminium (mg/L) & 240 & $0.3 \pm 0.1$ & 300 & $0.2 \pm 0.1$ & 0.2 & 0.7 \\
\hline Sulfate & 240 & $42.2 \pm 3.9$ & 300 & $36.8 \pm 3.3$ & 0.9 & 0.3 \\
\hline $\mathrm{H}_{2} \mathrm{O}_{2}(\mathrm{mg} / \mathrm{L})$ & 240 & $3.8 \pm 1.0$ & 300 & $1.1 \pm 0.2$ & 27.4 & 0.002 \\
\hline Temperature $\left({ }^{\circ} \mathrm{C}\right)$ & 240 & $28.2 \pm 0.2$ & 300 & $27.4 \pm 0.2$ & 1.5 & 0.001 \\
\hline
\end{tabular}

$N$ Number, SE Standard error, FTU Formazine turbidity unit, TDS Total disolved solids, LR Light rigid 


\section{Data analysis}

MedCalc statistical software version 15.8 (Medcalc Software bvba, Ostend Belgium; https://www.medcalc.org; 2015) was used to calculate the odd ratio and $95 \%$ confidence interval to assess the influence of various environmental variables on anopheline larval presence. Student test was performed to compare the physico-chemical characteristics between water bodies with and without anopheline larvae. Bivariate and multivariate logistic regression models were used to identify variable associated with presence of anopheline larvae. The significance level was fixed at $\alpha<0.05$. A linear discriminant function analysis was used to determine key factors associated with An. gambiae s.s. and Anopheles coluzzii larvae presence. Analyses were performed using SPSS Statistics for Windows, version 20 (SPSS Inc., Chicago, Ill., USA) and the R software version 3.5.2 (R Core Team (2018) R Foundation for Statistical Computing, Vienna, Austria URL https://www.R-project.org/).

\section{Results}

\section{Anopheline larvae distribution}

A total of 18696 aquatic habitats were prospected and 2942 (about 15.7\%) were found with anopheline larvae. The proportion of sites found with anopheline larvae varied significantly according to districts $(P<0.05)$. High anopheline larval densities $(>50$ larvae/breeding site) were recorded in $56.9 \%$ (1674/ 2942) of positive breeding sites and late instar larvae (L3, L4, pupae) were recorded in 69.3\% $(n=2038)$ habitats.

Anopheline larvae were found in a variety of breeding habitats. Puddles were the most common representing $51.6 \%$ of the total anopheline breeding sites. Tire prints, wells and drains represented 12.9, 11.7 and $11.3 \%$ respectively of breeding sites with anopheline larvae. The remaining breeding habitats (12.5\%) included containers (buckets and tires), foot prints, pits and river edges (Table 1). Most breeding sites with anopheline larvae had less than $1 \mathrm{~m}^{2}$ of surface. In almost all breeding sites, anopheline and culicine larvae were found in sympatry.

\section{Logistic regression analysis between anopheline larval presence and breeding habitats characteristics}

Bivariate logistic regression analyses were conducted to assess any association between anopheline larvae presence

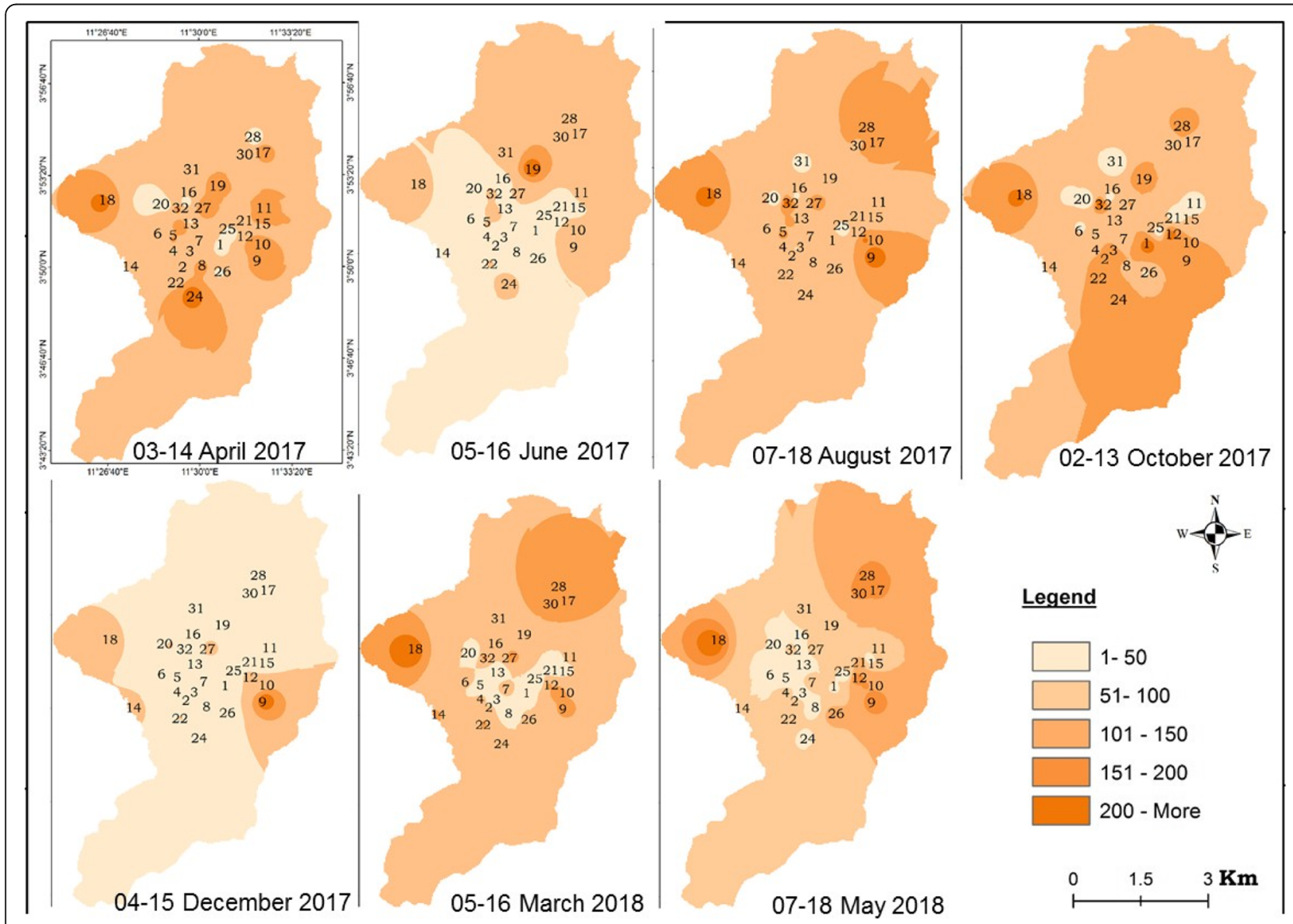

Fig. 2 Spatial and temporal distribution of temporary breeding habitats in the city of Yaoundé 
and some breeding sites characteristics. It appears that anopheline larvae were particularly frequent in the absence of predators (larvivorous fishes) $(O R=3.4$, $P<0.0001)$, absence of algae $(O R=1.5, P=0.06)$, and in breeding sites situated less than $10 \mathrm{~m}$ from living habitations $(O R=1.7, P=0.002)$ (Table 2).

\section{Comparison of physico-chemical characteristics of water bodies with and without anopheline larvae}

A total of 11 physico-chemical parameters were measured. Three parameters including turbidity $(P=0.001)$, hydrogen peroxide $(P=0.002)$ and temperature $(P=0.001)$ were significantly high in breeding sites with An. gambiae s.l. larvae than in breeding sites without larvae, while conductivity indicated a border significance $(P=0.05)$ (Table 3).

\section{Seasonal dynamics of anopheline breeding habitats in Yaoundé}

The spatial distribution of mosquitoes breeding habitats was highly variable from one season to the other. In some districts such as Nkolbisson, Ekounou-Palais, EkounouEkié, Tongolo, Ngousso, Santa-Barbara and Mvog-betsi, breeding habitats were present throughout the year due to permanent water bodies such as lakes or swamps. Permanent aquatic habitats were found to maintain anopheline presence during both the dry and rainy seasons. In most districts a drastic reduction of breeding habitats was recorded during the dry season (July-August and midNovember to February) whereas the rainy season (March to June and September to mid-November) corresponded to overall increase in larval habitat count and productivity (Figs. 2 and 3). Yet, some variations were recorded during the rainy season and could result from the variability or intensity of rainfall (Fig. 3).

\section{Land cover and spatial mapping of mosquitoes breeding sites distribution}

Yaoundé satellites images were examined to assess the evolution of different land cover parameters (Fig. 4) and their possible association with mosquito distribution. It clearly appeared from the images important changes in the vegetation cover and building index in and around the city between the two periods. Increased deforestation associated with increased human settlements was recorded. The forest was also replaced in different places by grassland which could be related to increase exploitation of the

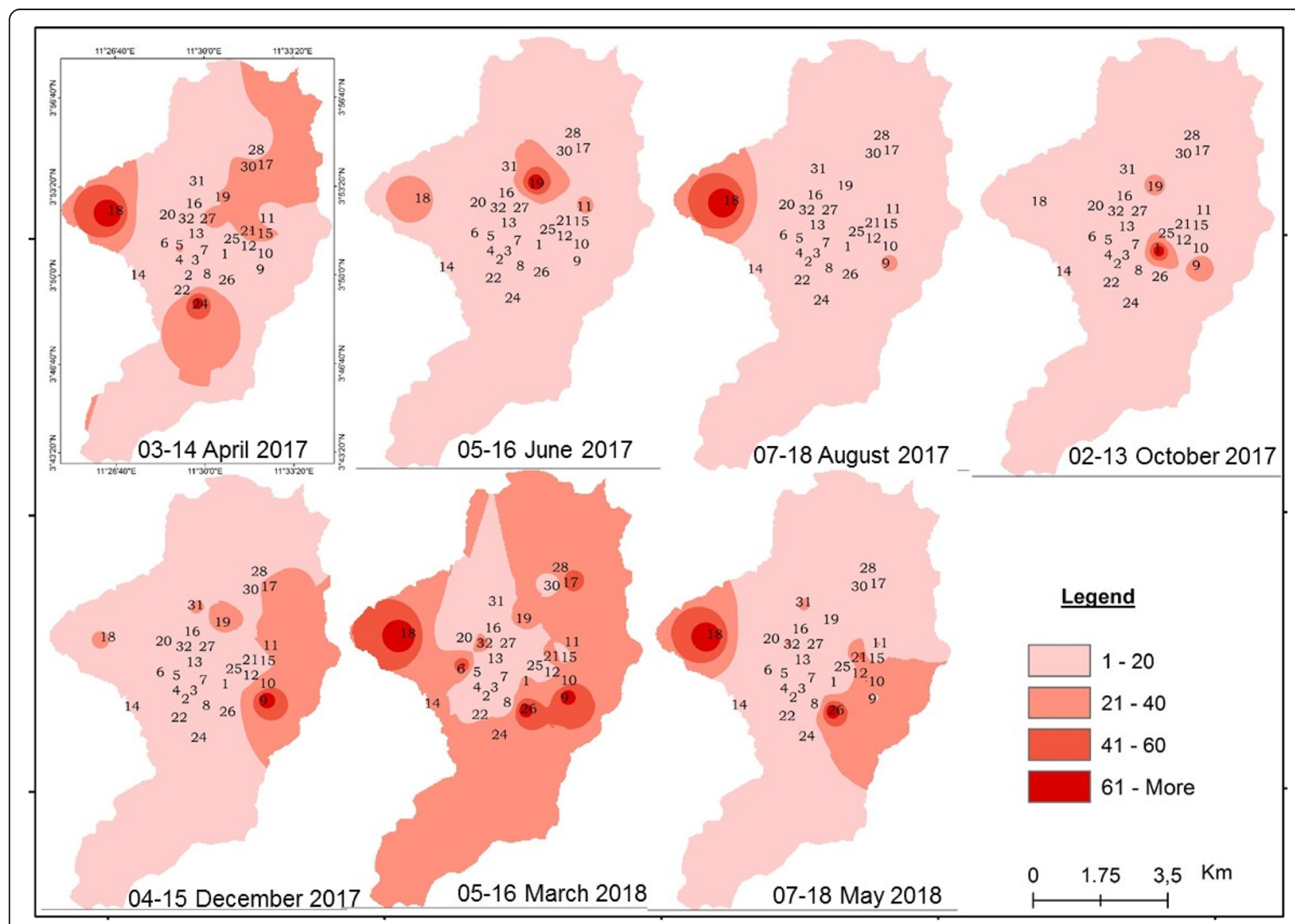

Fig. 3 Spatial and temporal distribution of breeding sites with anopheline larvae in the city of Yaoundé 
forest for agriculture. Four indexes were calculated to assess land use at different time periods, the Global Moran index; the Normalized Differenced Vegetation Index (NDVI), the Normalized Difference Water Index (NDWI), the Building Index (BI). The Global Moran index statistic to assess the existence of any significant clustering was undertaken. No significant variation was obtained $(I=$ 0.063 , $\mathrm{z}$-score $=1.28$ and $P=0.2$ ). The BI which include infrastructures such as buildings, houses, open space and road was also evaluated between the two periods calculations undertaken provided values ranging from 10.68 to 73.27 in 2017 and from 1 to 99 in 2018 (Figs. 5, 6). Variation of both the NDVI and NDWI for 2017 and 2018 are displayed in the Figs. 4 and 5.

\section{An. gambiae complex species diversity}

A total of 1237 larvae collected in 244 breeding habitats and identified morphologically as belonging to the An. gambiae complex were further processed molecularly to identify species of the complex. Both An. gambiae s.s. and An. coluzzii were recorded. An. coluzzii, was the most abundant species identified representing $91.1 \%$ of the total whereas An. gambiae s.s. represented $8.9 \%$ of the total. Both species were found in sympatry in 55 out of 244 (22.5\%) breeding habitats. An. gambiae s.s. larvae were collected alone in 2/244 breeding sites (0.8\%). An. coluzzii was recorded alone in $76.6 \%$ (187/244) breeding habitats. Both species were present in breeding sites in the majority of districts of Yaoundé (Fig. 7).

\section{Multivariate regression analysis to assess factors affecting An. gambiae s.s. and An. coluzzi distribution in breeding} sites

A multivariate analysis was used to assess the relationship between the presence of An. gambiae s.l. larvae and some environmental variables. A poor correlation was recorded with the first two axes of the diagram accounting for $15.5 \%$ of the total variance (Fig. 8). The first axis defined a gradient with An. coluzzii presence, anopheline density, distance to the nearest house, temperature, $A n$. gambiae s.s. presence and immediate environment. The second environmental gradient was essentially associated with Culex presence, culicine density, immediate environment, anopheline density and distance to the nearest house. A positive and significant correlation was recorded between An. gambiae s.s. and An. coluzzii larvae

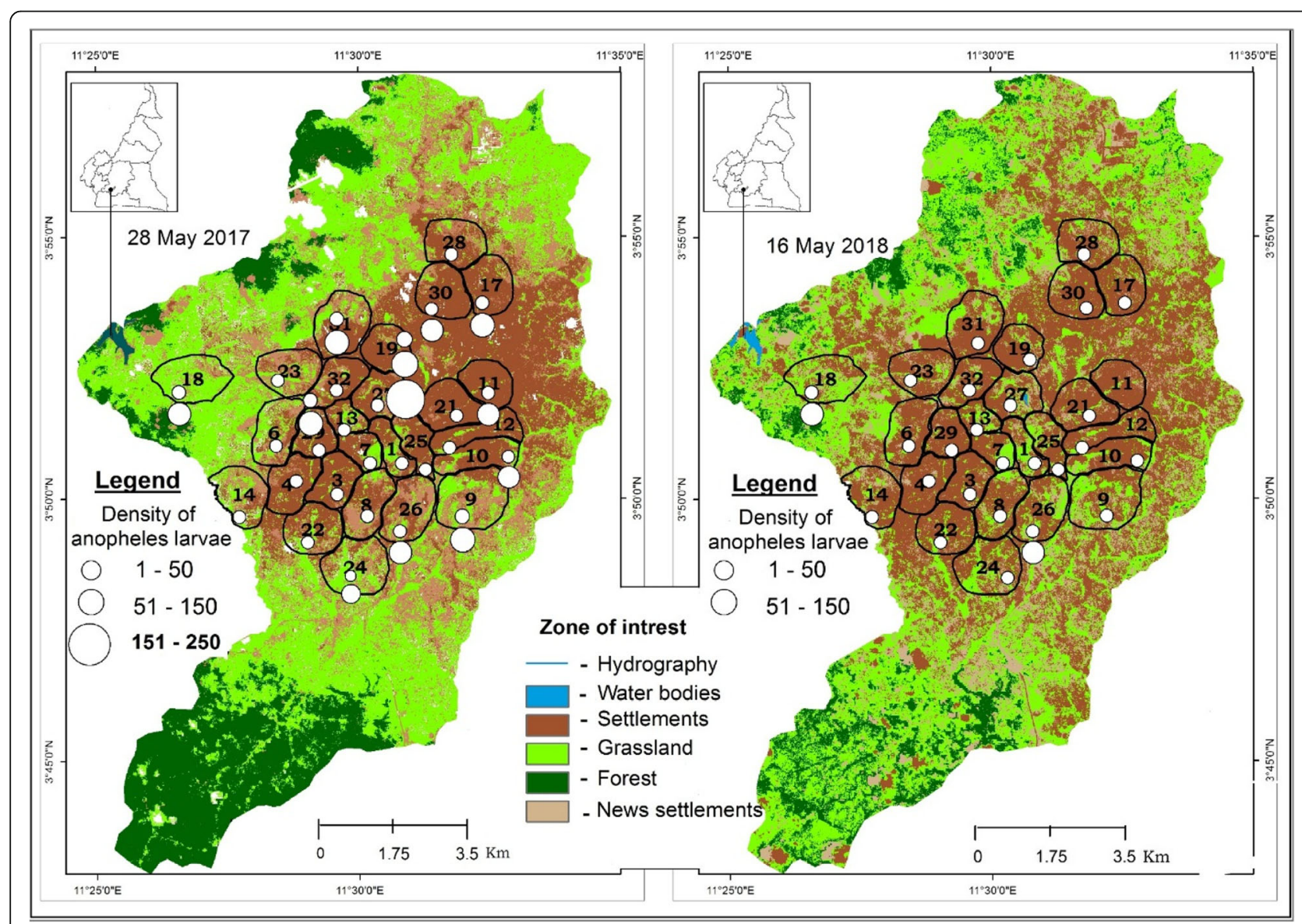

Fig. 4 Evolution of the land cover in Yaoundé between 2017 and 2018 and the density of anopheline larvae in breeding sites 


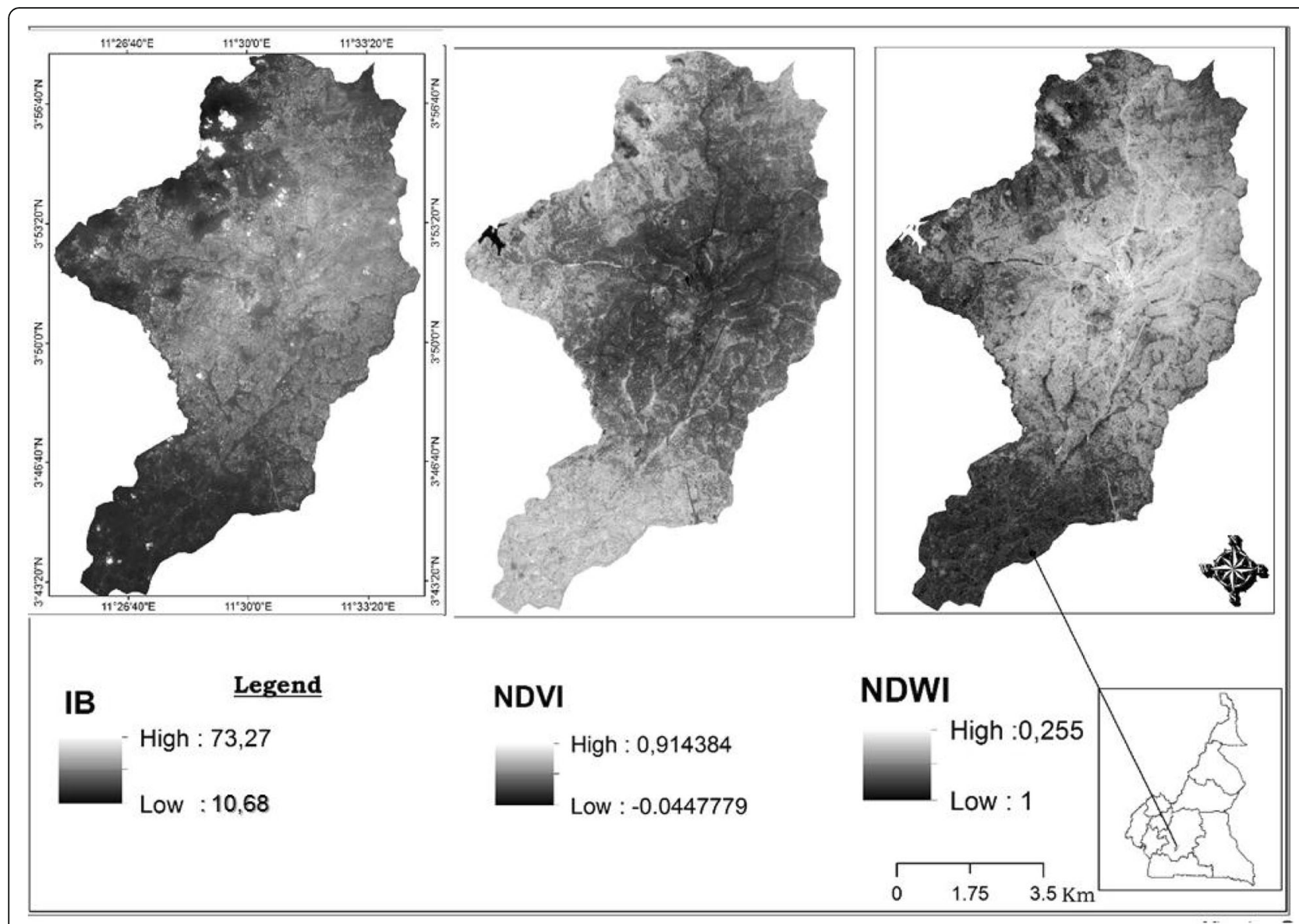

Fig. 5 Evolution of Building Index (BI), Normalised Difference Vegetation Index (NDVI) and Normalized Difference Water Index (NDWI) in 2017 in Yaoundé

distribution $(r=0.4 ; P<0.0001)$. The temperature and $\mathrm{pH}$ were positively correlated to the distribution of both An. gambiae s.s. and An. coluzzii larvae $(r>0.13)$.

\section{Discussion}

The study objective was to assess factors influencing the spatio-temporal distribution of Anopheles gambiae s.l. larvae in the city of Yaoundé. An. gambiae s.l. larvae were found to colonize a large number of habitats including temporary water collections, permanent sites and artificial habitats. This was in accordance with the high adaptation capacity of the species in urban settings [22, 48-50]. An. gambiae s.s. and An. coluzzii were recorded in sympatry in a high number of unpolluted (organic pollution) breeding sites. Yet Anopheles coluzzii was largely predominant with the densities outpassing by far those of An. gambiae s.s. This was in line with previous findings $[20,51,52]$ supporting the high adaptation capacity of An. coluz$z i i$ to the urban environment. A certain number of physico-chemical parameters were found to affect the distribution of An. gambiae s.l. larvae in breeding sites. These included conductivity, turbidity, organophosphates and temperature which were in high concentration in breeding sites with anopheline larvae. Organic pollution was reported as a major factor affecting the distribution of both species. Indeed, $A n$. coluzzii was reported to be more adapted to the presence of organic pollutants, whereas An. gambiae s.s. was not $[19,53,54]$. It is rather not known whether the reduction of organic pollutants in urban settings could favor recolonization of urban habitats by $A n$. gambiae s.s. and this deserves further investigations.

Seasonal variations of aquatic habitats containing anopheline larvae were registered. March-April was the period when high larval density was recorded. Rainfall appears as a major factor influencing the distribution of anopheline larvae in breeding sites. It is rather possible that current climatic changes are affecting mosquito distribution and vector borne diseases epidemiology $[55,56]$. In Cameroon since the late 1990s to date, an increase in temperature of + $0.4{ }^{\circ} \mathrm{C}$ compared to the period $1961-1990$ and a reduction in rainfall ranging from $-10 \%$ to $-20 \%$ have 


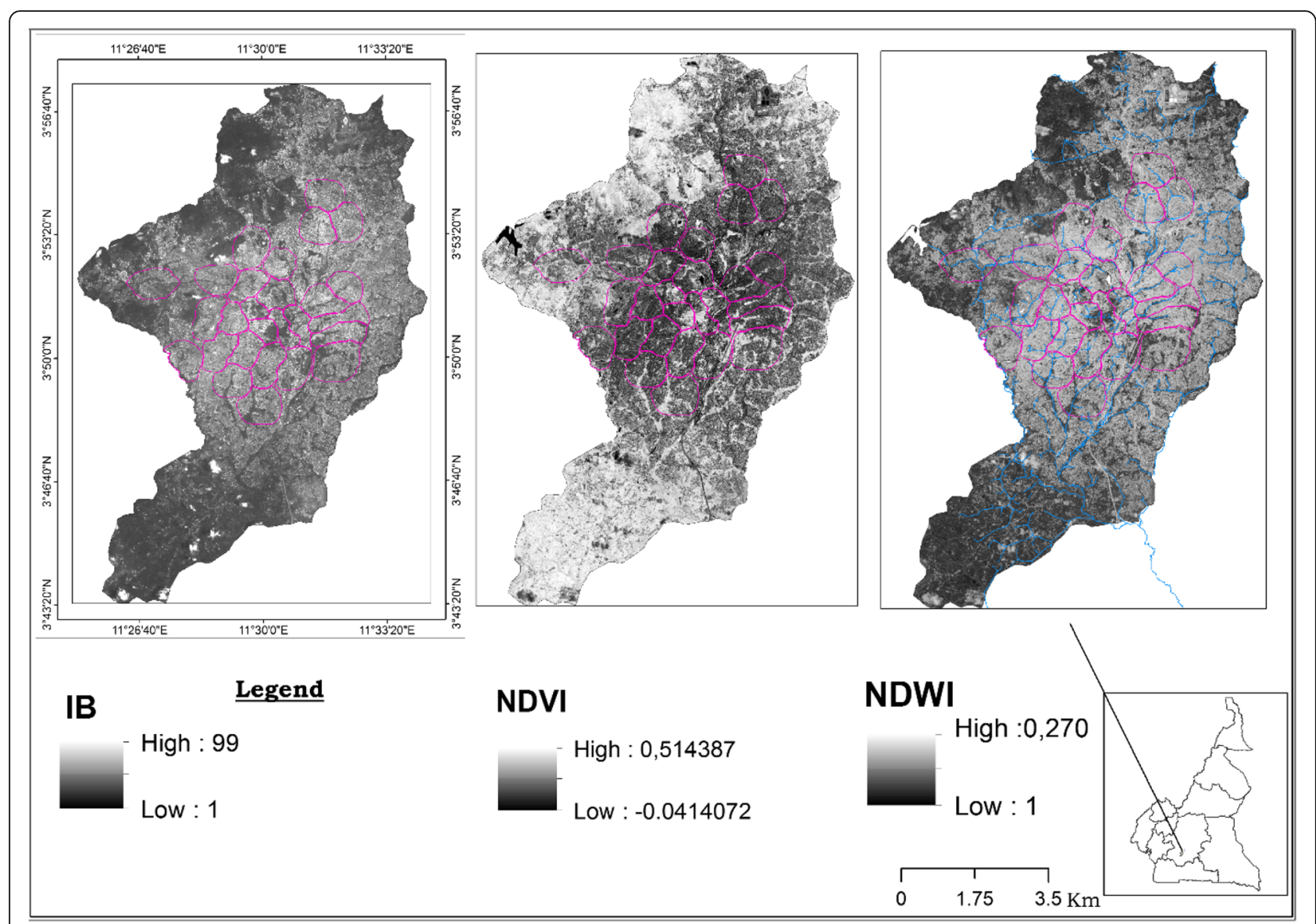

Fig. 6 Evolution of Building Index (BI), Normalised Difference Vegetation Index (NDVI) and Normalized Difference Water Index (NDWI) in 2018 in Yaoundé

been reported [57]. The density of larvae in breeding sites was highly variable and not dependent on the availability of aquatic habitats. The following could point to the influence of several factors such as environmental changes, the presence of pollutants in breeding sites, the availability of food resources or the presence of predators. The majority of breeding sites with anopheline larvae were temporary sites of less than $1 \mathrm{~m}$, with no vegetation or algae, no predators, with a depth of less than $1 \mathrm{~m}$. In Yaoundé in addition to temporary sites several permanent sites such as rivers edges, lacs, marshland exploited for agriculture are present all year long and contribute to maintain the presence of anopheline larvae in lowland areas. Although permanent sites were also recorded to harbor anopheline larvae, they were found to yield less larvae compare to temporary sites. This could result from the fact that, these sites are home to a wide range of invertebrate predators and competitors which could likely reduce mosquito larval density [58]. Several insects including odonata, toxorhynchitinae and culicine larvae (Culex tigripes) are known to be good predators of anopheline larvae and could influence the distribution and abundance of larvae in breeding habitats $[59,60]$. Predators are known to reduce mosquito abundance by direct predation of early instars, they could also prevent females to oviposite in breeding sites or could affect mosquito population through competition for food resources [59, 61-65].

During the dry season the practice of agriculture in lowland areas in many districts over large surfaces was found to contribute to the distribution and maintenance of anopheline larvae presence. The clearing of vegetation and the creation of wells or irrigation canals for agriculture were found to be favorable habitats for mosquitoes. Also the practice of agriculture by increasing sedimentation due to erosion or direct elimination of vegetation or rubbish in the river bed which can slow or block streams and decrease the water depth could create shallow waters ideal for mosquito breeding [66]. In Yaoundé there is an extension of urban agricultural practices in a high number of sites. The contribution of urban agriculture to anopheline burden and malaria transmission in the city of Yaoundé has not received so far enough attention 


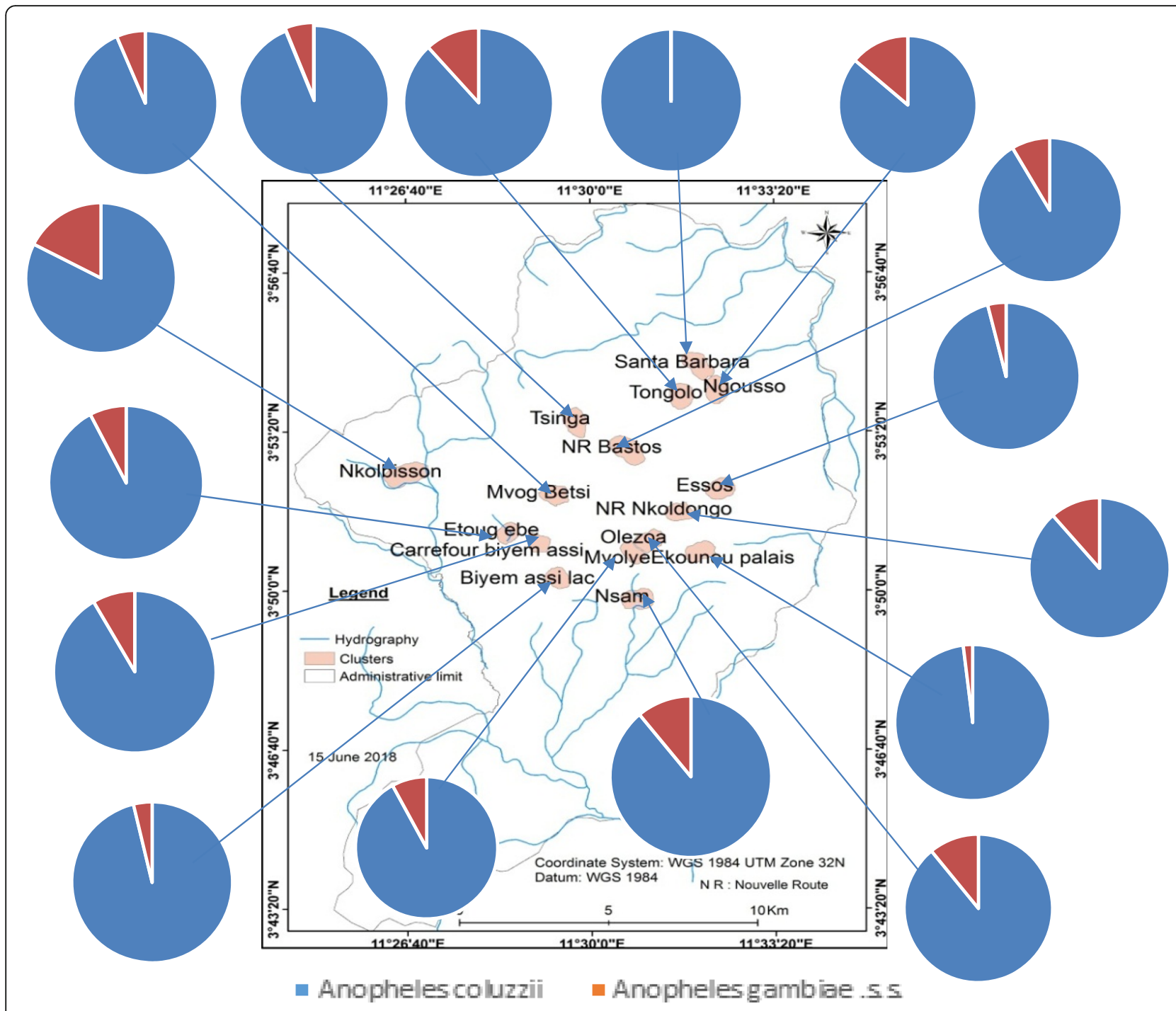

Fig. 7 Spatial distribution of Anopheles gambiae and An. coluzzii larvae in breeding sites of some districts of Yaoundé

as elsewhere [67-71] and could be key for the control and elimination of malaria in the city of Yaoundé. Also because several pesticides are frequently used for controlling pest in these settings, these compounds by exerting a high selection pressure on mosquito populations contribute to the rapid expansion of insecticide resistance in the urban environment and across the country $[22,71-73]$ and deserve further consideration.

Several other activities closely associated to unplanned urbanisation were found to create suitable breeding habitats for mosquitoes. This included construction of houses in lowland areas or public work activities within the city, stagnant water bodies resulting from pipe leaking, car washing activities and the absence of drainage system for stagnant water bodies [74, 75]. Similar observations have been made by previous studies in different epidemiological settings [75-78]. The study also highlighted the need for an integrated approach for controlling malaria transmission in the city of Yaoundé.

The use of GIS software for mapping breeding habitats distribution in the city of Yaounde provided important information that could be used for the management and supervision of larval control activities. This mapping showed rapid modification of the urban landscape with intense deforestation taking place around the city. GIS mapping contribution has been instrumental during the last decade in addressing issues related to malaria vector control in various setting across Africa [34, 79, 80]. The combination of field dataset and remotely sensed data provided a comprehensive picture of the changing landscape and mosquito distribution in the city of Yaoundé. From the analysis it appeared that the majority of anopheline breeding sites are found in lowland areas and that the pattern of mosquito distribution varied greatly 


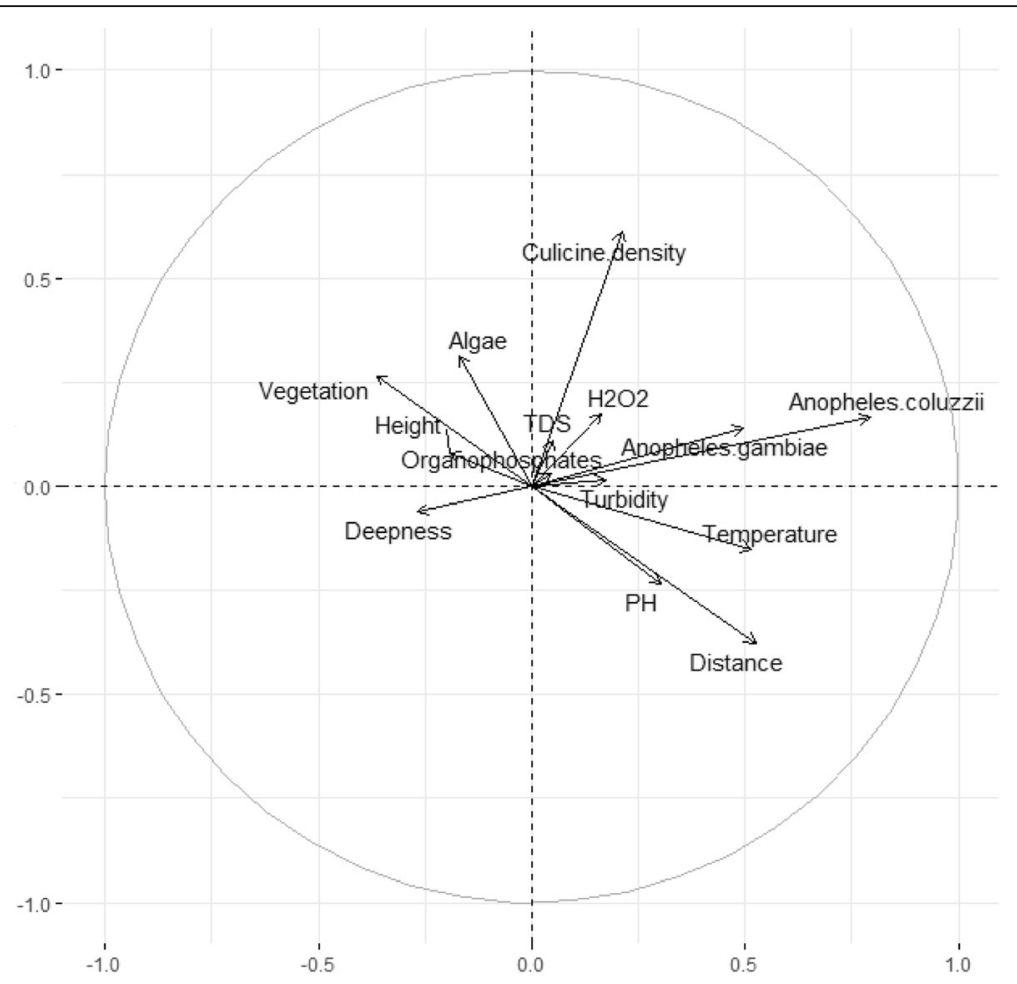

Fig. 8 Multiple component analysis showing relationship between An. gambiae s.s., An. coluzzi presence and some physical characteristics of breeding sites in Yaoundé

between 2017 and 2018. The calculation of the I Moran index permitted to determine estimates that could be used to prioritize habitats or hotspots needing further attention. According to Tokarz and Novak [80], clusters displaying high outputs are indicative of multiple sites of high larval productivity and could certainly contribute highly to the Anopheles burden and are the utmost importance and need to serve as the top priority for control. The ability to identify and treat these clusters could significantly reduce the density of vector populations [81]. In this regard, weekly samplings rather than monthly collections as done in the present study, could be indicated to better capture the evolution of breeding sites productivity. From the study, it appeared that lowland areas where agriculture was practiced, were the most affected and need further attention. In the case of larval control trial as what is under preparation for the city of Yaoundé, focusing on such areas could be determinant for successful control and elimination of malaria in the urban environment.

Limitations from the study could come from the fact that, it was conducted in some districts, and this study could not capture all the variability in the city of Yaoundé. Also, field samplings were mainly conducted in standing water. Therefore, mosquito larvae collection would be underestimated the presence of other anopheline species such An. funestus in Yaoundé.

\section{Conclusions}

The study provided a snapshot of the distribution of anopheline species before the implementation of a larval control trial in the city of Yaoundé. The study highlighted the fact that in addition to temporal sites in several hotspot areas mainly are associated to agricultural practices and contribute to perennial risk of malaria transmission in the city of Yaoundé. With the extension of the City, more efforts need to be undertaken in order to target hotspot areas such as marshlands exploited for agriculture and lakes, which contribute the most to malaria transmission. The use of larviciding or environmental management could be appropriate in the fight against malaria if these target hotspot areas where the use of LLINs could be insufficient for controlling malaria vectors.

\section{Supplementary information}

Supplementary information accompanies this paper at https://doi.org/10. 1186/s40249-019-0597-6.

Additional file 1. Multilingual abstracts in the five official working languages of the United Nations.

\section{Abbreviations}

BI: Bulding Index; DEM: Digital Elevation Model; DNA: Desoxyribonucleic acid; GIS: Geographic information system; GPS: Global positionning system;

LLINs: Long lasting insecticidal nets; NDVI: Normalised Difference Vegetation 
Index; NDWI: Normalized Difference Water Index; OR: Odd ratio;

PCR: Polymerase chain reaction; TDS: Total dissolved solid

\section{Acknowledgements}

Not applicable.

\section{Authors' contributions}

Conceived and designed the study protocol: CAN, participated in data collection: DDL, MM, TA, KCN, NDSM, KE, SCN, NCS, DBP, BR, TJC, CAN; critically revised the manuscript: CSW, $\Pi$; interpreted, analysed data and wrote the paper: CAN, DDL with contribution of other authors. All the authors read and approved the final version.

\section{Funding}

This work received financial support from Wellcome Trust Senior Fellowship in Public Health and Tropical Medicine (202687/Z/16/Z) to ANC. The funding body did not have any role in the design, collection of data, analysis and interpretation of data and in writing of the manuscript.

\section{Availability of data and materials}

\section{Not applicable.}

\section{Ethics approval and consent to participate}

The study was conducted under the ethical clearance N²016/11/832/CE/ CNERSH/SP delivered by the Cameroon National Ethics (CNE) Committee for Research on Human Health Ref D30-172/L/MINSANTE/SG/DROS/TMC of 04 April 2017.

\section{Consent for publication}

Not applicable.

\section{Competing interests}

The authors declare that they have no competing interests.

\section{Author details}

${ }^{1}$ Malaria Research Laboratory, Organization for the fight against Endemic diseases in Central Africa (OCEAC), P.O. Box 288, Yaoundé, Cameroon. ²Vector Borne Infectious Disease Unit of the Laboratory of Applied Biology and Ecology (VBID-LABEA), Department of Animal Biology, Faculty of Science, University of Dschang, P.O. Box 067, Dschang, Cameroon. ${ }^{3}$ Faculty of Science, University of Yaounde I, P.O. Box 337, Yaounde, Cameroon. ${ }^{4}$ Faculty of Health Sciences University of Buea, P.O. Box 63, Buea, Cameroon. ${ }^{5}$ Vector Biology Liverpool School of Tropical medicine Pembroke Place, Liverpool L3 5QA, UK.

Received: 5 June 2019 Accepted: 10 September 2019

Published online: 09 October 2019

\section{References}

1. Hay SI, Guerra CA, Tatem AJ, Atkinson PM, Snow RW. Urbanization, malaria transmission and disease burden in Africa. Nat Rev Microbiol. 2005:3:81-90.

2. Keiser J, Utzinger J, Caldas de Castro M, Smith TA, Tanner M, Singer BH. Urbanization in sub-saharan Africa and implication for malaria control. Am J Trop Med Hyg. 2004;71:118-27.

3. Klinkenberg E, McCall P, Wilson M, Amerasinghe F, Donnelly M. Impact of urban agriculture on malaria vectors in Accra, Ghana. Malar J. 2008;7:151.

4. Fillinger U, Kannady K, William G, Vanek MJ, Dongus S, Nyika D, et al. A tool box for operational mosquito larval control: preliminary results and early lessons from the urban malaria control Programme in Dar Es Salaam, Tanzania. Malar J. 2008;7(1):20.

5. Eder M, Cortes F, Teixeira de Siqueira Filha N, Araújo de França GV, Degroote S, Braga C, et al. Scoping review on vector-borne diseases in urban areas: transmission dynamics, vectorial capacity and co-infection. Infect Dis Poverty. 2018;7(1):90.

6. Tatem AJ, Gething PW, Smith DL, Hay SI. Urbanization and the global malaria recession. Malar J. 2013;12:133.

7. Kigozi R, Baxi S, Gasasira A, Sserwanga A, Kakeeto S, Nasr S, et al. Indoor residual spraying of insecticide and malaria morbidity in a high transmission intensity area of Uganda. PLoS One. 2012;7:e42857.

8. Fournet F, Jourdain F, Bonnet E, Degroote $S$, Ridde V. Effective surveillance systems for vector-borne diseases in urban settings and translation of the data into action: a scoping review. Infect Dis Poverty. 2018;7(1):99.
9. Pastorino B, Muyembe-Tamfum JJ, Bessaud M, Tock F, Tolou H, et al. Epidemic resurgence of chikungunya virus in democratic Republic of the Congo: identification of a new central African strain. J Med Virol. 2004;74(2):277-82.

10. Leroy EM, Nkoghe D, Ollomo B, Nze-Nkogue C, Becquart P, Grard G, et al. Concurrent chikungunya and dengue virus infections during simultaneous outbreaks, Gabon, 2007. Emerg Infect Dis. 2009;15(4):591-3.

11. Moyen N, Thiberville SD, Pastorino B, Nougairede A, Thirion L, Mombouli JV, et al. First reported chikungunya fever outbreak in the republic of Congo, 2011. PLoS One. 2014:9(12):e115938.

12. Greenwood B. The epidemiology of malaria. Ann Trop Med Parasitol. 1997;91:763-9.

13. Bhatt S, Weiss DJ, Cameron E, Bisanzio D, Mappin B, Dalrymple U. The effect of malaria control on plasmodium falciparum in Africa between 2000 and 2015. Nature. 2015;526:207-11.

14. Doumbe-Belisse P, Ngadjeu C, Sonhafouo-Chiana N, Talipouo A, DjamoukoDjonkam L, Kopya E, et al. High malaria transmission sustained by Anopheles gambiae s.l. occurring both indoors and outdoors in the city of Yaoundé, Cameroon [version 1; peer review: 2 approved]. Wellcome Open Research. 2018;3:164.

15. Antonio-Nkondjio C, Defo-Talom B, Tagne-Fotso R, Tene-Fossog B, Ndo C, Lehman L. High mosquito burden and malaria transmission in a district of the city of Douala, Cameroon. BMC Infect Dis. 2012;12:275.

16. Mourou J, Coffinet T, Jarjaval F, Pradines B, Amalvict R, Rogier C, et al. Malaria transmission and insecticide resistance of Anopheles Gambia in Libreville and Port-Gentil, Gabon. Malar J. 2010;9:321.

17. Mourou JR, Coffinet T, Jarjaval F, Cotteaux C, Pradines E, Godefroy L. Malaria transmission in Libreville: results of a one year survey. Malar J. 2012;11:40.

18. Onwujekwe O, Dike N, Ojukwu J, Uzochukwu B, Ezumah N, Shu E, et al. Consumers stated and revealed preferences for community health workers and other strategies for the provision of timely and appropriate treatment of malaria in Southeast Nigeria. Malar J. 2006;5:117.

19. Tene Fossog B, Kopya E, Ndo C, Menze-Djantio B, Costantini C, Njiokou F. Water quality and Anopheles gambiae larval tolerance to pyrethroids in the cities of Douala and Yaounde (Cameroon). J Trop Med. 2012;2012:429817.

20. Kamdem C, Fossog BT, Simard F, Etouna J, Ndo C, Kengne P, et al. Anthropogenic habitat disturbance and ecological divergence between incipient species of the malaria mosquito Anopheles gambiae. PLoS One. 2012;7:e39453.

21. Mlacha YP, Chaki PP, Mwakalinga VM, Govella NJ, Limwagu AJ, Paliga JM, et al. Fine scale mapping of malaria infection clusters by using routinely collected health 1 facility data in urban Dar Es Salaam, Tanzania. Geospat Health. 2017;12(1):294.

22. Antonio-Nkondjio C, Tene Fossog B, Kopya E, Poumachu Y, Menze Djantio B, Ndo C. Rapid evolution of pyrethroid resistance prevalence in Anopheles gambiae populations from the cities of Douala and Yaounde (Cameroon). Malar J. 2015:14:155

23. Nwane P, Etang J, Chouaibou M, Toto J, Kerah-Hinzoumbe C, Mimpfoundi R. Trends in DDT and pyrethroid resistance in Anopheles gambiae s.s. populations from urban and agro-industrial settings in southern Cameroon. BMC Infect Dis. 2009:9:163.

24. Tusting LS, Thwing J, Sinclair D, Fillinger U, Gimnig J, Bonner KE. Mosquito larval source management for controlling malaria. Cochrane Database Syst Rev. 2013;8:CD008923.

25. Maheu-Giroux M, Castro MC. Impact of community-based larviciding on the prevalence of malaria infection in Dar Es Salaam, Tanzania. PLoS One. 2013; 8(8):e71638.

26. Mpofu M, Becker P, Mudambo K, de Jager C. Field effectiveness of microbial larvicides on mosquito larvae in malaria areas of Botswana and Zimbabwe. Malar J. 2016;15(1):586.

27. Afrane YA, Mweresa NG, Wanjala CL, Gilbreath lii TM, Zhou G, Lee MC. Evaluation of long-lasting microbial larvicide for malaria vector control in Kenya. Malar J. 2016;15:577.

28. Fillinger U, Ndenga B, Githeko A, Lindsay SW. Integrated malaria vector control with microbial larvicides and insecticide-treated nets in western Kenya: a controlled trial. Bull World Health Organ. 2009;87:655-65.

29. Fillinger $U$, Lindsay SW. Larval source management for malaria control in Africa: myths and reality. Malar J. 2011;10:353.

30. Mbare $\mathrm{O}$, Fillinger $\mathrm{U}$, Lindsay $\mathrm{S}$. Dose response tests and semi field evaluation of lethal and sub-lethal effects of slow release pyriproxifen granules (Sumilarv0.5G) for the control of the malaria vectors Anopheles gambiae sensu lato. Malar J. 2013;12:94.

31. WHO recommendations for achieving universal coverage with longlasting insecticidal nets in malaria control. Geneva: World Health Organization; 2013. 
32. Muema JM, Bargul JL, Njeru SN, Onyango JO, Imbahale SS. Prospect for malaria control through manipulation of mosquito larval habitats and olfactory-mediated behavioural responses using plant-derived compounds. Parasit Vectors. 2017;10(1):184.

33. Robert V, Macintyre K, Keating J, Trape J, Duchemin J, Warren M, et al. Malaria transmission in urban sub-saharan Africa. Am J Trop Med Hyg. 2003;68:169-76.

34. Dongus S, Nyika D, Kannady K, Mtasiwa D, Mshinda H, Fillinger U, et al. Participatory mapping of target areas to enable routine comprehensive larviciding of malaria vector mosquitoes in Dar Es Salaam, Tanzania. Int J Health Geogr. 2007;6:37.

35. Bousema T, Stresman G, Baidjoe AY, Bradley J, Knight P, Stone W, et al. The impact of hotspot-targeted interventions on malaria transmission in Rachuonyo South District in the Western Kenyan highlands: a cluster-randomized controlled trial. PLoS Med. 2016;13(4): e1001993.

36. Letouzey R. Notice de la carte phytogéographique du Cameroun au 1/500 000: Domaine de forêt dense humide toujours verte. Toulouse: Institut de la Carte international de la végétation; 1985. p. 95-144.

37. Suchel JB. Quelques remarques à propos de la répartition des pluies au Cameroun durant la période sèche 1969-1973. Hommes et Terres du Nord. 1983:3(1):24-8.

38. Suchel J. Les climats du Cameroun. Institut de la carte internationale de la végétation, Fasc; 1987. p. 1186.

39. Wethé J, Radoux M, Tanawa E. Assainissement des eaux usées et risques socio - sanitaires et environnementaux en zones d'habitat planifié de Yaoundé (Cameroun). VertigO - la revue électronique en sciences de l'environnement [En ligne], vol. 4; 2003. p. 4741

40. Kabaria CW, Molteni F, Mandike R, Chacky F, Noor AM, Snow RW, et al. Mapping intra-urban malaria risk using high resolution satellite imagery: a case study of Dar Es Salaam. Int J Health Geogr. 2016; 15(1):26.

41. Moran PA. Notes on continuous stochastic phenomena. Biometrika. 1950;37:17-23.

42. Wagtech P. Water quality testing; 2012. p. 1-139.

43. Service M. Mosquito ecology. Field sampling methods. London and New York: Elsevier Applied Science; 1993.

44. Edwards FW. Mosquitoes of the Ethiopian region. III, Culicine adults and pupae. London: brit. Mus. (Nat. Hist.); 1941

45. Gillies M, Coetzee M. A supplement to the Anophelinae of Africa south of the Sahara (Afrotropical region). 1st ed. Johannesburg: South Afr Inst Med Res; 1987.

46. Santolamazza F, Calzetta M, Etang J. Distribution of knock-down resistance mutations in Anopheles gambiae molecular forms in west and west-Central Africa. Malar J. 2008;7:74.

47. Livak KJ, Schmittgen TD. Analysis of relative gene expression data using real-time quantitative PCR and the 2- $\Delta \Delta C T$ method. Methods. 2001;25(4):402-8.

48. Mbida Mbida A, Etang J, Akono Ntonga P, Eboumbou Moukoko C, AwonoAmbene $P$, Tagne D, et al. Nouvel aperçu sur l'écologie larvaire d'Anopheles coluzzii Coetzee et Wilkerson, 2013 dans l'estuaire du Wouri, LittoralCameroun. Bull SociÉTÉ Pathol Exot. 2017;110(2):92-101.

49. Kenea O, Balkew M, Gebre-Michael T. Environmental factors associated with larval habitats of anopheline mosquitoes (Diptera: Culicidae) in irrigation and major drainage areas in the middle course of the rift valley, Central Ethiopia. J Vector Borne Dis. 2011;48:85-92.

50. Mweresa CK, Mukabana WR, Omusula P, Otieno B, Van Loon JJA, Takken W. Enhancing attraction of African malaria vectors to a synthetic odor blend. J Chem Ecol. 2016;42(6):508-16.

51. Gimonneau G, Pombi M, Choisy M, Morand S, Dabiré RK, Simard F. Larval habitat segregation between the molecular forms of the mosquito Anopheles gambiae in a rice field area of Burkina Faso, West Africa. Med Vet Entomol. 2012;26(1):9-17.

52. Simard F, Ayala D, Kamdem G, Pombi M, Etouna J, Ose K. Ecological niche partitioning between Anopheles gambiae molecular forms in Cameroon: the ecological side of speciation. BMC Ecol. 2009;9:17.

53. Tene-Fossog B, Ayala D, Acevedo P, Kengne P, Ngomo I, Makanga B. Habitat segregation and ecological character displacement in cryptic African malaria mosquitoes. Evol Appl. 2015:8:326-45

54. Tene Fossog B, Poupardin R, Costantini C, Awono-Ambene H, Wondji C, Ranson $\mathrm{H}$. Resistance to DDT in an urban setting: common mechanisms implicated in both $\mathrm{M}$ and $\mathrm{S}$ forms of Anopheles gambiae in the city of Yaoundé Cameroon. PLoS One. 2013;8:e61408.

55. Sinka M, Bangs M, Manguin S, Coetzee M, Mbogo C, Hemingway J. The dominant Anopheles vectors of human malaria in Africa, Europe and the Middle East: occurrence data, distribution maps and bionomic précis. Parasit Vectors. 2010;3:117.
56. Caminade $\mathrm{C}$, Mclntyre $\mathrm{KM}$, Jones $\mathrm{AE}$. Impact of recent and future climate change on vector-borne diseases. Ann N Y Acad Sci. 2019; 1436(1):157-73.

57. Sighomnou D. Analyse et definition des regimes climatiques et hydrologiques du cameroun: perspectives d'evolution des ressources en eau: thèse de doctorat. Yaoundé: University of Yaoundé; 2004. p. 1-150.

58. Knight TM, Chase JM, Goss CW, Knight JJ. Effects of interspecific competition, predation, and their interaction on survival and development time of immature Anopheles quadrimaculatus. J Vector Ecol. 2004;29:277-84.

59. Kweka EJ, Zhou G, Munga S, Lee MC, Atieli HE, Nyindo M. Anopheline larval habitats seasonality and species distribution: a prerequisite for effective targeted larval habitats control programmes. PLoS One. 2012;7:e52084.

60. Kweka EJ, Zhou G, Gilbreath TM, Afrane Y, Nyindo M, Githeko AK, et al. Predation efficiency of Anopheles gambiae larvae by aquatic predators in western Kenya highlands. Parasit Vectors. 2011;4:110

61. Wellborn GA, Skelly DK, Werner EE. Mechanisms creating community structure across a freshwater habitat gradient. Ann Rev Ecol System. 1996;27(1):337-63.

62. Mwangangi JM, Muturi EJ, Shililu J, Muriu SM, Jacob B, Kabiru EW, et al. Survival of immature Anopheles arabiensis (Diptera: Culicidae) in aquatic habitats in Mwea rice irrigation scheme, Central Kenya. Malar J. 2006:5:114.

63. Frank LD, Sallis JF, Saelens BE, Leary L, Cain L, Conway TL. The development of a walkability index: application to the neighborhood quality of life study. Br J Sports Med. 2010;44:924-33.

64. Roux O, Robert V. Larval predation in malaria vectors and its potential implication in malaria transmission: an overlooked ecosystem service? Parasit Vectors. 2019;12(1):217.

65. Collins C, Bonds J, Quinlan M, Mumford J. Effects of the removal or reduction in density of the malaria mosquito, Anopheles gambiae sl, on interacting predators and competitors in local ecosystems. Med Vet Entomol. 2019;33(1):1-15.

66. Mereta ST, Yewhalaw D, Boets P, Ahmed A, Duchateau L, Speybroeck N Physico- chemical and biological characterization of anopheline mosquito larval habitats (Diptera: Culicidae): implications for malaria control. Parasit Vectors. 2013;6:320.

67. Yadouleton A, Asidi A, Djouaka R, Braima J, Agossou C, Akogbeto M. Development of vegetable farming: a cause of the emergence of insecticide resistance in populations of Anopheles gambiae in urban areas of Benin. Malar J. 2009;8:103.

68. Djouaka R, Riveron JM, Yessoufou A, Tchigossou G, Akoton R, Irving $\mathrm{H}$, et al. Multiple insecticide resistance in an infected population of the malaria vector an. Funestus in Benin. Parasit Vectors. 2016;9:453.

69. Djouaka R, Atoyebi SM, Tchigossou G, Riveron JM, Irving H, Akoton R, et al. Evidence of a multiple insecticide resistance in the malaria vector Anopheles funestus in south West Nigeria. Malar J. 2016;15:565.

70. Chouaïbou MS, Fodjo BK, Fokou G, Allassane OF, Koudou BG, David JP, et al Influence of the agrochemicals used for rice and vegetable cultivation on insecticide resistance in malaria vectors in southern Côte d'Ivoire. Malar J. 2016;15(1):426.

71. Chouaibou M, Etang J, Brevault T, Nwane P, Hinzoumbe CK, Mimpfoundi R, et al. Dynamics of insecticide resistance in the malaria vector Anopheles gambiae (s.l.) from an area of extensive cotton cultivation in northern Cameroon. Tropical Med Int Health. 2008;13:476-86.

72. Antonio-Nkondjio C, Poupardin R, Tene BF, Kopya E, Costantini C, Awono-Ambene $P$, et al. Investigation of mechanisms of bendiocarb resistance in Anopheles gambiae populations from the city of Yaoundé, Cameroon. Malar J. 2016;15(1):424.

73. Antonio-Nkondjio C, Sonhafouo-Chiana N, Ngadjeu CS, Doumbe-Belisse P, Talipouo A, Djamouko-Djonkam $L$, et al. Review of the evolution of insecticide resistance in main malaria vectors in Cameroon from 1990 to 2017. Parasit Vectors. 2017;10:472

74. Ngom R. Spatial and statistical prediction of urban malaria in Yaoundé: a social and environmental modelling approach for health promotion: Dissertation, Heidelberg University; 2010. http://opus. bszbw.de/phhd/volltexte

75. Antonio-Nkondjio C, Fossog B, Ndo C, Djantio B, Togouet S, AwonoAmbene $P$. Anopheles gambiae distribution and insecticide resistance in the cities of Douala and Yaounde (Cameroon): influence of urban agriculture and pollution. Malar J. 2011;10:154

76. Silva AX, Jander G, Samaniego H, Ramsey JS, Figueroa CC. Insecticide resistance mechanisms in the green peach aphid Myzus persicae (Hemiptera: Aphididae) I: a transcriptomic survey. PLoS One. 2012;7:e36366. 
77. Keating J, Maclntyre K, Mbogo C, Githeko A, Regens JL, Swalm C. A geographic sampling strategy for studying relationships between human activity and malaria vectors in urban Africa. Am J Trop Med Hyg. 2003;68:357-65.

78. De Silva PM, Marshall JM. Factors contributing to urban malaria transmission in sub-saharan Africa: a systematic review. J Trop Med. 2012;2012:819563.

79. Ageep TB, Cox J, Hassan MM, Knols BG, Benedict MQ, Malcolm CA, et al. Spatial and temporal distribution of the malaria mosquito Anopheles arabiensis in northern Sudan: influence of environmental factors and implications for vector control. Malar J. 2009;8(1):123.

80. Tokarz R, Novak RJ. Spatial-temporal distribution of Anopheles larval habitats in Uganda using GIS/remote sensing technologies. Malar J. 2018;17(1):420.

81. Lutambi AM, Chitnis N, Briët OJ, Smith TA, Penny MA. Clustering of vector control interventions has important consequences for their effectiveness: a modelling study. PLoS One. 2014;9(5):e97065.

Ready to submit your research? Choose BMC and benefit from:

- fast, convenient online submission

- thorough peer review by experienced researchers in your field

- rapid publication on acceptance

- support for research data, including large and complex data types

- gold Open Access which fosters wider collaboration and increased citations

- maximum visibility for your research: over $100 \mathrm{M}$ website views per year

At $\mathrm{BMC}$, research is always in progress.

Learn more biomedcentral.com/submissions 